Filip Woźniak

Wydział Filozoficzny

Uniwersytet Jagielloński

\title{
RELIGIA I RELIGIJNE. JOHNA DEWEYA FILOZOFICZNA ANALIZA I KRYTYKA JEZZYKA RELIGII
}

\section{Wstęp}

John Dewey, klasyk amerykańskiego pragmatyzmu, w Polsce znany jest głównie z prac z zakresu pedagogiki i estetyki ${ }^{1}$. Jednak w swojej bogatej twórczości Dewey dotykał również zagadnień religijnych. W niniejszym artykule chcę zrekonstruować filozofię religii Deweya zawartą w eseju A Common Faith. Skupię się na jego krytyce teologii i języka, którym operuje tradycyjna religia. Odniosę się do czterech problemów:

1. doświadczenia religijnego i jego krytyki;

2. natury przekonań religijnych;

3. dosłownego i symbolicznego rozumienia przekonań religijnych;

4. rozumienia tytułowego przeciwstawienia rzeczownika religia i przymiotnika religijne (religious) ${ }^{2}$.

Pierwsze zagadnienie odnosi się do tradycyjnych koncepcji teologicznych, które widzą w doświadczeniach tego rodzaju źródło pewnej specjalnej wiedzy

${ }^{1}$ Więcej na temat recepcji J. Deweya w Polsce w artykule K. Wilkoszewskiej Recepcja filozofii Johna Deweya w Polsce, http://www.deweycenter.uj.edu.pl/tekst_wilkoszewska.html (dostęp: 25.05.2017).

${ }^{2} \mathrm{Z}$ podobnym problemem $\mathrm{w}$ kwestii tłumaczenia angielskiego przymiotnika używanego w funkcji rzeczownikowej mamy do czynienia w polskiej estetyce. Angielskie an aesthetic i the aesthetic tłumaczy się zazwyczaj jako estetyczność. Ja zdecydowałem się tłumaczyć Deweyowskie religious niezgodnie z uzusem zakorzenionym w estetyce i w sposób nienaturalny dla języka polskiego, ale dokładnie odpowiadający angielskiemu oryginałowi jako religijne, a nie religijność. Uznałem, że za takim ruchem przemawiają racje, po pierwsze, filozoficzne, które przedstawię na końcu artykułu, oraz, po drugie, językowe - religijność ma w polszczyźnie ustalone konotacje konfesyjno-dewocyjne, które mogą skierować interpretację koncepcji Deweya na niezgodne z duchem jego teorii tory. 
na temat świata i Boga. Krytyka Deweya wychodzi z pozycji metody empirycznej oraz pragmatyzmu - jako filozofii powszechnego doświadczenia, która odrzuca uprzywilejowane, nadnaturalne sposoby wglądu w rzeczywistość. Drugi i trzeci problem dotyczą tego, jak powinniśmy rozumieć prawdy religijne i treści doświadczeń o charakterze religijnym. Postaram się wykazać za Deweyem, że w kwestii interpretacji treści religijnych panują chaos i dwuznaczność, które utrudniają działanie. Czwarty, kluczowy punkt dotyczy pozytywnego stanowiska Deweya, w którym proponuje on własne rozumienie religijności. Stanowisko to każe oddzielić religię od religijnego. Rozróżnienie to ma doprowadzić do lepszego zrozumienia prawdziwie religijnych elementów doświadczenia. Będę chciał wykazać zasadność tego przeciwstawienia oraz fakt, że ta różnica terminologiczna pociąga ważne metafizyczne i praktyczne konsekwencje.

\section{Doświadczenie religijne}

John Dewey określał się słowami „,naturalistyczny empirysta”, „empiryczny naturalista", przedstawiciel „naturalistycznego humanizmu"’3. Sednem tak określonego stanowiska jest przyjęcie doświadczenia za punkt wyjścia, metodę oraz cel wszystkich aktywności, badań i dociekań. Doświadczenie to zespół interakcji między człowiekiem a jego środowiskiem; sposób zaspokajania potrzeb ludzkich. Doświadczenie w pragmatystycznej wizji Deweya jest treściowo pełniejsze niż bierna i poznawcza empirystyczna koncepcja doświadczenia ${ }^{4}$. Ma ono charakter poznawczy, praktyczny i estetyczny; są w nim elementy racjonalne i emocjonalne; składa się z faz aktywności, gdy wywieramy wpływ na środowisko, i faz pasywnych, gdy pobieramy z niego energię. Życie jest ciągiem następujących po sobie doświadczeń. Ów ciąg zaczyna się od doświadczeń zwierząt i innych istot, z nich wychodzi ${ }^{5}$. Stąd bierze się naturalistyczne podejście Deweya, który widzi w naszych potrzebach, ambicjach, ideach, wszystkich dziedzinach kultury przedłużenie natury, a nie rzeczywistość od niej oddzielną i jakościowo różną. Wynika z tego egalitarne i demokratyczne nastawienie Deweya, że ludzie mają podobne potrzeby i potencjalnie równe możliwości realizacji tych potrzeb. Nie ma żadnych specjalnych klas doświadczeń, które mogą mieć tylko ograniczone grupy ludzi, doświadczenie wyrasta bowiem ze wspólnej istoty gatunkowej i współdzielonego środowiska.

${ }^{3}$ J. Dewey, Experience and Nature, London 1929, s. 1a.

${ }^{4}$ Por. J. Schulkin, Pragmatic Naturalism and Social Cooperation, „The Journal of Speculative Philosophy" 2014, vol. 28, no. 1, s. 68.

${ }^{5}$ J. Dewey, Art as Experience, New York 1980, s. 14, 18. 
Wydawałoby się, że również doświadczenie religijne, tak chętnie rozważane przez filozofów religii ${ }^{6}$, powinno znaleźć akceptację Deweya. Odrzuca on jednak doświadczenie religijne traktowane jako specjalny rodzaj doświadczenia. Bezpośrednim powodem krytyki doświadczenia religijnego jako doświadczenia sui generis było podejście ówczesnych liberalnych teologów, którzy chcieli traktować doświadczenie religijne jako empiryczny, ,naukowy” dowód na istnienie Boga. Dewey wyśmiewa takie stanowisko jako podszywające się pod naukowy empi$\mathrm{ryzm}^{7}$. Uprawianie teologii w taki pseudonaukowy sposób jest obarczone poważnymi błędami. Dewey nie neguje istnienia jakości religijnej w doświadczeniu, lecz odrzuca założenie, że istnieją pewne specyficzne klasy doświadczeń, które można nazwać „doświadczeniami religijnymi”, tak jak istnieją doświadczenia moralne, poznawcze lub estetyczne, stanowiące podstawę twierdzeń z tych dziedzin. Wedle krytykowanych przez Deweya teoretyków doświadczenia religijne mają, analogicznie, uzasadniać twierdzenia teologii.

Żeby wyjaśnić ten problem, Dewey powołuje się na świadectwo nawróconego człowieka ${ }^{8}$. W wyniku specyficznego doświadczenia człowiek ów wyszedł z kryzysu egzystencjalnego i zyskał świadomość jedności z Bogiem, dzięki której przez wiele lat nie odczuwał rozpaczy ani zwątpienia. Dewey zwraca uwagę, że nie można powątpiewać w prawdziwość zmiany, jaka zaszła w życiu tego człowieka, lecz doszukiwanie się przyczyny tej zmiany w działaniu osobowego Boga chrześcijaństwa musi budzić wątpliwości. Przedstawiciele innych wyznań, a nawet osoby bezwyznaniowe mają podobne doświadczenia, lecz interpretują je na różne sposoby. Twierdzenie, że to specjalne doświadczenie, które powoduje tak głęboką zmianę w życiu, jest wynikiem relacji z osobowym Bogiem chrześcijaństwa i musi być zatem dowodem na Jego istnienie, jest zależną od kultury i wychowania interpretacją, która zostaje nałożona ex post na doświadczenie. Podobne rozumowanie Dewey stosuje wobec doświadczenia mistycznego ${ }^{9}$. Praktyki mistyczne odnajdujemy w wielu odległych czasowo i geograficznie kulturach. Ich interpretacje są jednak wielokrotnie krańcowo różne. Nie mamy powodu negować realności tego, co zachodzi w doświadczeniach tych ludzi. Ich interpretacje doświadczeń nie wynikają jednak z samych doświadczeń, ale są zapożyczane z kultury, w której wychowała się dana osoba. Skoro doświadczenie o charakterze religijnym nie wiąże się z żadną konkretną treścią doktrynalną, jest ono potencjalnie dostępne wszystkim ludziom, nie ogranicza się do wyznawców jakiejś konkretnej religii.

${ }^{6}$ Por. rozdział Doświadczenie religijne wczoraj $i$ dziś, w: L. Dupré, Inny wymiar, Kraków 2003.

${ }^{7}$ J. Dewey, A Common Faith, New Haven 1960, s. 10-11.

${ }^{8}$ Tamże, s. 11-12.

${ }^{9}$ Tamże, s. 36-38. 
W doświadczeniu dana jest nam wyłącznie zmiana na lepsze, poczucie sensu i harmonii, w którym jednak nie ma żadnej treści pozwalającej określić, co jest przyczyną owej zmiany: Bóg, bogowie czy jeszcze jakiś inny byt. Przypisywanie tej zmiany w życiu działaniu ponadnaturalnego bytu ma wyjaśnienie psychologiczne: doświadczenie o jakości ${ }^{10}$ religijnej ma dla doznającego tak dużą wartość, wprowadza tak istotną zmianę w jego życiu, że uznaje on je za skutek działania tego, co dana kultura określa jako najświętsze ${ }^{11}$.

To właśnie skutek doświadczenia o charakterze religijnym - lepsze przystosowanie do życia, reorientacja i reorganizacja naszych postaw - sprawia, że nadajemy tego rodzaju doświadczenia głęboko emocjonalnie nacechowane miano religijnego. Dewey zauważa, że taki skutek można osiągnąć na różne sposoby: zmiana ta „Czasami wynika z poświęcenia się idei; czasem wywołuje ją fragment wiersza, który otwiera nową perspektywę; czasem zachodzi tak, jak w przypadku Spinozy - uznawanego swego czasu za ateistę - w wyniku filozoficznej refleksji" 12 .

Poczyniwszy te krytyczne uwagi, Dewey proponuje pozytywne określenie roli doświadczenia o charakterze religijnym. Podąża tutaj śladami Williama Jamesa $^{13}$, który spostrzegł, że religia może głęboko zmieniać ludzkie nastawienie do życia, pozwala znosić przeciwności losu dzięki harmonizacji jednostki z siłami Wszechświata. Dewey określa jakość religijną jako dającą procesom życia dogłębne i trwałe wsparcie. Taki stan może być osiągnięty przez zmianę naszego stosunku do świata, dobrowolną, niewymuszoną zewnętrznymi okolicznościami przemianę woli rozumianej jako organiczna pełnia naszego bytu, a nie zmiana pewnego szczególnego pragnienia ${ }^{14}$. O pełni tej możemy mówić wyłącznie w kontekście wyobraźni. Całość naszego bytu, a tym bardziej Wszechświata, nie jest nam bowiem dana w wyniku obserwacji, nie jest obiektem wiedzy ani refleksji ${ }^{15}$. W tym punkcie Dewey zgadza się z tradycyjnymi filozofami religii, którzy widzieli w doświadczeniu religijnym coś różnego od naszych normalnych, codziennych stanów woli i rozumu. Jednakże tam, gdzie filozofowie religii postulują istnienie pewnej specjalnej władzy podmiotu, która ma odpowiadać za owe niecodzienne treści świadomości, Dewey poprzestaje na wskazaniu wyobraźni - władzy używanej w normalnych sytuacjach.

${ }^{10}$ „Jakość” to termin techniczny metafizyki Deweya. Jakość nadaje charakter, określa, jaką naturę ma dane doświadczenie i jednocześnie indywidualizuje, wyodrębnia pojedyncze doświadczenie z ciągu doświadczeń, jakim jest życie i historia. Więcej na ten temat w: P. Gutowski, Między monizmem a pluralizmem, Lublin 2002, s. 104-111.

${ }^{11}$ J. Dewey, A Common Faith..., s. 13.

12 Tamże, s. 14.

${ }^{13}$ W. James, Odmiany doświadczenia religijnego, przeł. J. Hempel, Warszawa 2011.

${ }^{14}$ J. Dewey, A Common Faith..., s. 16-17.

15 Tamże, s. 19. 


\section{Przekonania religijne}

Mimo swej niekognitywnej natury religie starają się ujmować wierzenia w teologiczne systemy, których prawda jest gwarantowana przez autorytet ich domniemanego nadnaturalnego autora. Dewey wskazuje ${ }^{16}$, że istnieje różnica między poglądami na temat ostatecznych celów a prawdami intelektu. Przekonania na temat idealnych celów moralnych są z natury praktyczne, nie zaś intelektualne (w języku Kanta można powiedzieć, że odpowiada za nie rozum praktyczny, a nie - teoretyczny). Intelekt uczestniczy oczywiście w analizowaniu i precyzowaniu tych celów, lecz nie z niego pochodzi ich ważność; żaden fakt ani sąd nie stanowi dowodu dla przekonań moralnych, przekonania te swoją siłę czerpią z ideału. Krytycy takiego podejścia twierdzą, że idealny przedmiot wierzeń jest w istocie realnie egzystujący, stanowi rdzeń i ostateczny cel bytu, jedynie nasze skończone władze poznawcze nie potrafią odnaleźć go w świecie. Dewey odrzuca to stanowisko jako zabójcze dla wiary. Jeśli traktujemy naszą wiarę jako zaistniały fakt, negujemy moralną moc wiary. Aktywna, transformująca siła wiary znika, jeśli jej przedmiot zaczynamy traktować jako zaistniały fakt. Równocześnie w ten sposób zaczynamy wplatać w nasz system teologiczny przekonania metafizyczne. Obserwowany świat fizyczny nie zgadza się bowiem z naszymi przekonaniami na temat „religijnych faktów”. Tworzymy więc abstrakcyjne konstrukcje intelektualne, które mają tłumaczyć, jak to jest, że uznawane przez nas treści idealne są jednocześnie faktyczne i nieobserwowalne w rzeczywistości. Wyobraźnia jest wówczas zaprzęgnięta wyłącznie do projektowania fantastycznych obrazów świata, a nie do wysiłku przeobrażania rzeczywistości, by jak najbardziej odpowiadała ideałowi.

Równocześnie podejście, wedle którego przekonania religijne to w istocie zbiór sądów o istniejących faktach, zabija również możliwość poznania ${ }^{17}$. Dewey zauważa, że chociaż nie uznaje się już powszechnie, iż Objawienie się dokonało, jest już zakończone, dalej uważa się, że wyznaczyło nam ono ogólne ramy wiedzy i postęp może nastąpić wyłącznie wewnątrz tych ram i w zgodzie z nimi. Wiara o jakości religijnej nie ma tego rodzaju ograniczeń. Nie przyjmuje, że istnieje jedna droga do prawdy, lecz ufnie podchodzi do naturalnych sił ludzkich, w których wyniku zdobywamy więcej wiedzy o świecie. To właśnie dzięki jakości religijnej-jakości dającej harmonię i jedność ze światem - zyskujemy nowe siły i zaufanie do nich, co pozwala z ufnością traktować nasze wysiłki i dążenia w poszukiwaniu prawdy. To również ta jakość zmienia zwykłą wiarę moralną, żywioną przez każdego z nas (a która w języku Deweya oznacza, jak sądzę, po

\footnotetext{
16 Tamże, s. 20-21.

17 Tamże, s. 26.
} 
prostu system etyczny), w wiarę religijną, rozumianą jako siła przemieniająca świat, by odpowiadał ideałom.

Problem, jaki w przypadku religii historycznych generują odkrycia naukowe, stanowi dla Deweya dowód, że jego rozgraniczenie religii i religijnego jest słuszne i - jeśli zostanie wprowadzone w życie - owocne ${ }^{18}$. Nauka bowiem podkopuje podstawy licznych dogmatów religii historycznych. Liberalni teologowie próbują bronić swoich systemów teologicznych, dowodząc, że obalone dogmaty w rzeczywistości nigdy nie stanowiły istotnych części tych systemów. Dewey zauważa, że problem nie dotyczy poszczególnych dogmatów, lecz metody, wedle której dogmaty są odkrywane, uzasadniane i włączane do systemu. Jakość religijna nie jest związana z poszczególnymi dogmatami, a właściwie - tu Dewey jest naprawdę radykalny - z żadnym dogmatem, nawet tym o istnieniu Boga. Należy porzucić twierdzenia, które mają mieć specjalny, konstytutywny dla religii status i do których dochodzi się w pewien szczególny sposób. Jakkolwiek odkrycia naukowe mogą podkopać religię, nie zaszkodzą wierze religijnej, której sensem są dogłębna i trwała zmiana naszego życia oraz idealny cel, jaki pragniemy wprowadzić w życie. Nauka prowadzi do tego samego celu, dając nam informacje, dzięki którym możemy lepiej realizować nasze pragnienia, podejmować lepsze wybory i, w konsekwencji, zmieniać świat, by lepiej odpowiadał ideałowi.

Kontrargument zwolenników religii historycznych, jakoby wiedza osiągana przy użyciu pewnych specjalnych doświadczeń była pewniejsza, lepsza i bardziej adekwatna $\mathrm{w}$ stosunku do religii, jest o tyle wątpliwy, że pozytywny wniosek wywodzi z negatywnej przesłanki ${ }^{19}$. To, że obecnie nie potrafimy badać naukowo cudownych fenomenów, które uznaje się za przynależne do dziedziny religii, nie uzasadnia, dlaczego miałyby one być całkowicie wyłączone z normalnej, doświadczeniowo-naukowej metody badania. Rozumowanie Deweya może ilustrować przykład burzy. W społeczeństwach pierwotnych nie potrafiono wyjaśnić tego rodzaju fenomenów i dlatego wskazywano na ich nadnaturalne pochodzenie. Jeśli przyjęlibyśmy argument obrońców religii, nie moglibyśmy rozwijać meteorologii, wchodziłaby ona bowiem na teren zarezerwowany dla religii. $Z$ tej perspektywy nie do utrzymania jest podział rzeczywistości na dwie dziedziny: pierwszej, do której stosuje się normalna metoda doświadczeniowo-naukowa, i drugiej, w której do prawdy dochodzi się pewnymi specjalnymi metodami.

18 Tamże, s. 32-33.

19 Tamże, s. 34-35. 


\section{Przekonanie religijne - jego sens}

Dewey zauważa ${ }^{20}$, że liberalni teologowie starają się bronić religijnych przekonań przed zakusami świeckiego, naukowego rozumu, twierdząc, że przekonania te, podobnie jak rytuały i ceremonie religijne, mają symboliczny charakter. Ów symboliczny sens polega na tym, że przekonania religijne odnoszą się do rzeczywistości transcendentnej, która nie jest nam dana w normalnym doświadczeniu, wykracza poza nasze możliwości poznawcze, więc opisać ją możemy wyłącznie za pomocą mniej lub bardziej adekwatnych metafor. Wiara wyrażana symbolami nie jest więc wiedzą, lecz raczej najlepszym dostępnym nam zamiennikiem wiedzy. Dewey wyciąga z takiego ujęcia wniosek, że również treści Objawienia, które uznajemy za opis faktów, np. opis czynów postaci historycznych, musimy uznać za symbole ideałów moralnych. To zdaje się być zgodne z wcześniejszym spostrzeżeniem, że prawdziwa wiara moralna nie wypływa z wiedzy, lecz jest odbiciem ideału moralnego, do którego dążymy. Jednakże zachodzi tutaj pewna dwuznaczność. Chociaż teologowie są w stanie zgodzić się, że treści religijne są symboliczne, to dalej przyjmują, że mówią one o faktach. Dewey krytykuje takie stanowisko, gdyż nie dodaje ono niczego do siły, z jaką wywierają na nas wpływ przekonania religijne, lecz wystawia je na krytykę naukową jako wątpliwe intelektualnie.

Wyjaśnić należy jeszcze, co to znaczy, że przekonania religijne dotyczą treści idealnych ${ }^{21}$. Dewey zaznacza, że nie chodzi o to, iż sposób, w jaki istnieją obiekty naszej wiary, różni się in plus od naszej skończonej egzystencji. Idealny oznacza tutaj cel i dążenie ludzkie, które popychają nas i dają nam siłę do realizacji stojących przed nami możliwości. W tym sensie to, co Dewey nazywa Bogiem, nie jest tym, o czym mówią religie historyczne. Nie jest to bowiem istniejący przedwiecznie, specjalny byt. To raczej siła jednocząca i skupiająca wartości idealne, a zarazem wzywająca do stałego wysiłku pracy, walki o ich wcielanie w ludzkie życie. Ideał, rozumiany jako istniejący, nie zachęca do aktywności, rozleniwia i paraliżuje, nie wymaga od człowieka pracy, jego czyny bowiem nie wpływają, nie oddziałują na ten ideał i nie łączą się z nim. Najlepiej widać ową własność ideału postrzeganego jako aktualny w religiach, których członkowie wierzą w wielką bitwę sił Zła i Dobra przy końcu świata oraz w ostateczne pokonanie Zła w tej bitwie. Bitwa ta nadaje sens dziejom i poszczególnym egzystencjom, ale - będąc w pewnym sensie już zaistniałą - nie wyjaśnia, jaką wartość mają nasze ciągłe zmagania ze Złem w życiu codziennym, skoro ostatecznie i tak, niejako bez naszego udziału, zostanie ono pokonane. Podobnie niepokojącej konkluzji nie można by wywieść, gdyby ów ideał potyczki Dobra

\footnotetext{
${ }^{20}$ Tamże, s. 40-41.

21 Tamże, s. 42-44.
} 
i Zła traktować jako daną nam możliwość, której realizacja zależy od nas i do której urzeczywistnienia jesteśmy wezwani. Ostateczne Dobro, Pełnia i Bóg są zatem możliwościami, realnymi w tym względzie, że przyciągającymi nas i zachęcającymi do zmiany niedoskonałego świata, lecz jednocześnie tylko możliwymi, ponieważ jedynie rzecz jeszcze nie zaistniała może domagać się aktualizacji.

\section{Religia a religijne}

Na podstawie wcześniejszych uwag na temat doświadczenia oraz metod dociekania prawd religijnych można odnieść wrażenie, że religia nie różni się od innych dziedzin życia, a w szczególności jest nieomal tożsama z nauką. Do pewnego stopnia jest to uzasadniony wniosek, Dewey był bowiem przeciwnikiem ostrych, analitycznych rozróżnień, które dzielą doświadczenie, każą myśleć o fundamentalnie różnych rodzajach doświadczenia i praktyk kulturowych. Każde doświadczenie, przynajmniej potencjalnie, ma wiele różnych, ale homogenicznych aspektów, sensów, które - w zależności od układu czynników obecnych $\mathrm{w}$ doświadczeniu - składają się na doświadczenia różnego typu ${ }^{22}$. Podobnie w przypadku doświadczenia o charakterze religijnym powinniśmy mówić raczej o kontinuum intensywności występowania jakości religijnej - od doświadczeń zgoła pozbawionych takiej jakości, do doświadczeń nią przepełnionych.

Napięcie między zasadniczą ontologiczną jednorodnością doświadczenia a wymagającą konceptualizacji funkcjonalną różnorodnością jego aspektów Dewey wyraża specyficznym zabiegiem terminologicznym. Wyróżnia bowiem religię (religion), poszczególne religie (a religion) oraz religijne (religious).

Religia, jako określenie natury fenomenów religijnych lub minimalnej wspólnej treści fenomenów tego rodzaju, jest dla Deweya terminem nieomal pustym ${ }^{23}$. Patrząc bowiem na różnorodność, często krańcowo odmiennych, praktyk i wierzeń, koncepcji obiektu kultu, celów i motywacji stojących za praktykami religijnymi, spotykanych w różnych religiach historycznych, dochodzi do wniosku, że nie mają one ze sobą niemal nic wspólnego. Natura religii pozostaje niemożliwa do zdefiniowania. Do podobnej negatywnej konkluzji dochodzono czasami w filozofii religii lub religioznawstwie ${ }^{24}$. Inaczej sprawa ma się $\mathrm{z}$ definicją funkcjonalną, która ma wyjaśnić, czym jest konkretna religia (a religion), a nie religia

${ }^{22}$ Por. K. Wilkoszewska, Sztuka jako rytm życia, Kraków 2003, s. 90, 98-104.

${ }^{23}$ J. Dewey, A Common Faith..., s. 3-8.

${ }^{24}$ Por. A. Bronk, Why Is a Presuppositionless and in This Sense Objective Study of Religion Impossible?, „Anthropos” 2013, Bd. 108, H. 1, s. 231-239. 
w ogólności. Religia jest to system wierzeń i praktyk o mniej lub bardziej rozbudowanej organizacji instytucjonalnej ${ }^{25}$.

Trzecie kluczowe pojęcie to religijne (religious) ${ }^{26}$. Dewey wybrał przymiotnik, ponieważ słowo to nie denotuje żadnego bytu - wierzeń, praktyk lub instytucji, jak w przypadku religii. Religijne oznacza postawę (attitude), która nie jest ontologicznie niezależnym bytem, dającym się ująć w teologiczne lub instytucjonalne ramy. Mówimy tutaj o nastawieniu, które nie daje się charakteryzować przedmiotowo, jako skierowane na pewne specyficzne byty (np. fetysze, dusze lub bóstwa) lub dążące do specyficznych celów (np. zbawienia). Nastawienie religijne może być skierowane na dowolny obiekt, dążyć do dowolnego celu i chcieć realizować dowolny ideał. Tym, co wyróżnia postawę religijną od innych postaw, jest jej siła, natężenie. Jest to stan, w którym człowiek całą swoją egzystencją dąży do realizacji możliwości wskazanej przez wyobraźnię. Religijne jest tutaj tym, co aktywne, pracowicie dążące do zmiany.

Rozdzielenie religii i religijnego ma na celu emancypację tego drugiego. Za takim krokiem stoją dwa powody. Pierwszy jest związany z tym, co już zostało powiedziane na temat ograniczeń religii historycznych: Objawienia, które hamuje nasze poznanie, oraz Boga rozumianego jako zastany, faktyczny byt, który w ten sposób odwodzi od zadania, jakim jest urzeczywistnianie w życiu najwyższych wartości. Drugi jest taki, że wielu ludzi porzuca religie historyczne, a wraz z nimi wszelką religijność. W ten sposób ludzie ci zubażają swoje doświadczenie, zamykając się na jednoczącą i przeobrażającą moc religijnego. Uświadamiając im, że religijne nie jest koniecznie związane ze zniechęcającymi ich religiami historycznymi, otwieramy ich na dobroczynne działanie tego nastawienia.

Na koniec chciałbym rozważyć metafilozoficzne znaczenie strategii terminologicznej Deweya. Na pierwszy rzut oka powyższe rozróżnienie na religię i religijne wydaje się dziwaczne i nienaturalne. Za tym rozdziałem przemawia przede wszystkim przeciwstawienie własności obu tych fenomenów. Religia w sensie rzeczownikowym to pewnego rodzaju byt, pewna wydzielona egzystencja. Zakłada to substancjalizację omawianego zjawiska. Wskazuje to również sposób definiowania - przez ograniczenie przedmiotowe. W dodatku system wierzeń, praktyki itd. to dość ,stabilne" cechy. Tymczasem religijne jest przedmiotowo puste, definiowane formalnie, jakościowo. Ten antysubstancjalizm znajduje dobry wyraz w użyciu przymiotnika, który naturalnie nakierowuje nas na jakość, relację. W ten sposób Deweyowi udaje się wprowadzić terminologię, która utrudnia naszemu językowi filozoficznemu, przywykłemu do obiektualizowania i substancjalizowania, traktowanie obu zjawisk jako rzeczy, przedmiotów.

25 J. Dewey, A Common Faith..., s. 9.

${ }^{26}$ Tamże, s. 9-10. 


\section{Bibliografia}

Bronk A., Why Is a Presuppositionless and in This Sense Objective Study of Religion Impossible?, „Anthropos” 2013, Bd. 108, H. 1, s. 231-239.

Dewey J., A Common Faith, New Heven 1960.

Dewey J., Art as Experience, New York 1980.

Dewey J., Experience and Nature, London 1929.

Dupré L., Inny wymiar, Kraków 2003.

Gutowski P., Między monizmem a pluralizmem, Lublin 2002.

James W., Odmiany doświadczenia religijnego, przeł. J. Hempel, Warszawa 2011.

Schulkin J., Pragmatic Naturalism and Social Cooperation, „The Journal of Speculative Philosophy" 2014, vol. 28, no. 1, s. 52-78.

Wilkoszewska K., Sztuka jako rytm życia, Kraków 2003.

Streszczenie

\section{Religia i religijne. Johna Deweya filozoficzna analiza i krytyka języka religii}

Niniejszy artykuł jest próbą zrekonstruowania problemu religii w filozofii Deweya, a w szczególności jego krytyki teologii i języka, którym operuje tradycyjna religia. Autor skupił się na trzech problemach: 1. doświadczenie religijne i jego krytyka; 2. natura przekonań religijnych; 3 . dosłowne i symboliczne rozumienie sądów pochodzących z doświadczenia o charakterze religijnym; 4. rozumienie tytułowego przeciwstawienia religii i religijnego. Ostatni z tych punktów jest kluczowy; dotyczy pozytywnego stanowiska Deweya, w którym proponuje on własne rozumienie religijności. Stanowisko to każe oddzielić religię od religijnego, co ma doprowadzić do lepszego zrozumienia prawdziwie religijnych elementów doświadczenia.

\section{Summary}

\section{Religion and religious. John Dewey's philosophical analysis and criticism of the language of religion}

The following paper attempts to reconstitute the problem of religion in Dewey's philosophy, in particular his criticism of theology and language used by traditional religion. The author focuses on three issues: 1. Religious experience and its criticism; 2. Nature of religious beliefs; 3 . Literal and symbolic understanding of judgments derived from religious experience; 4. Understanding of title opposition religion and religious. The last of those is a key point; it concerns 
Dewey's positive position in which he proposes his own understanding of religion. This position requires separating religion from religious which lead to a better understanding of true religious elements of experience. 